\title{
Relationships between Color Perception of the Dress and Functional, Postural Lateral Preferences, Some Morphogenetic Traits and Chewing Side Preference
}

\author{
Elbisenin Renk Algısı ile Fonksiyonel, Postural Lateral Tercihler, Bazı \\ Morfogenetik Özellikler ve Çiğneme Tarafı Tercihi Arasındaki İlişkiler
}

\author{
Özlem Ergül Erkeç ${ }^{1 *}$, Neşe Çölçimen ${ }^{2}$, Sıddık Keskin ${ }^{3}$ \\ ${ }^{1}$ Department of Physiology, Faculty of Medicine, V an Yuzuncu Yil University, Van, Turkey \\ ${ }^{2}$ Department of Histology and Embryology, Faculty of Medicine, V an Yuzuncu Yil University, Van, Turkey \\ ${ }^{3}$ Department of Biostatistics, Faculty of Medicine, Van Yuzuncu Yil University, Van, Turkey
}

\begin{abstract}
Objectives: The aim of this study is to investigate the relationship between the color perception of the dress and functional, postural lateral preferences of some morphometric traits and chewing side preference.

Materials and Methods: Information on color perception of the dress, handedness, footedness, eyedness, earedness, hand clasping, arm folding, hand clapping, leg crossing, earlobe attachment, tongue rolling, blood group and chewing side was collected from 240 individuals.

Results: $18.3 \%$ of participants described the dress as blue-black, $40.4 \%$ as white-gold, $5.4 \%$ as blue-brown, $20.8 \%$ as switch and $15.0 \%$ as something else. No differences in gender, handedness, footedness, earedness, eyedness, hand clasping, hand clapping, leg crossing, earlobe attachment and preferred chewing side were found for the color perception of the dress. There was a significant relationship between groups in arm folding and tongue rolling ability. There was also a significant relationship between arm folding and eyedness. We found a switch from blue-brown, blue-black, white-gold or something else colors initially to blue-brown, blueblack, white-gold or something else colors in switch group.

Conclusion: Since there was little information about relationship between laterality and the dress color, this study was conducted and a significant relationship between these two subjects is reported for the first time in the present study in our knowledge.
\end{abstract}

Key Words: Arm folding, handedness, laterality, the dress, tongue rolling

\section{Introduction}

Brain lateralization is defined as that the two hemispheres of the brain are not completely

\section{ÖZET}

Amaç: $\mathrm{Bu}$ çalışmanın amacı elbisenin renk algısı ile fonksiyonel, postural lateral tercihler, baz1 morfogenetik özellikler ve çiğneme tarafı tercihleri arasındaki ilişkileri tespit etmektir.

Gereç ve Yöntem: Elbisenin renk algisı ile el tercihi, ayak tercihi, göz tercihi, kulak tercihi, el parmaklarını birbirine geçirme, kol kavuşturma, el çırpma, bacak bacak üstüne atma, kulak memesi yapışıklığı, dil kıvırma, kan grubu ve çiğneme tarafı tercihi hakkındaki bilgiler 240 , kişiden topland.

Bulgular: Katılımcıların \%18.3'ü elbiseyi mavi-siyah, $\% 40.4$ 'ü beyaz-altın, \%5.4'ü mavi-kahverengi, \%20.8'i değişken ve \%15.0'i farklı bir renk olarak tanımladı. Elbisenin renk algisı için gruplar arasında cinsiyet, el tercihi, ayak tercihi, kulak tercihi, göz tercihi, el parmaklarını birbirine geçirme, el çırpma, bacak bacak üstüne atma, kulak memesi yapışıklığ ve çiğneme tarafi bakımından anlamlı fark bulunmamıştır. Gruplar arasında kol katlama ve dil kıvırma becerileri bakımından anlamlı bir ilişki bulunmuştur. Kol katlama ve göz tercihi arasında da anlamlı bir ilişki tespit edilmiştir. Değişken grupta başlangıçta mavi-kahverengi, mavi-siyah, beyazaltın veya farklı bir renkten, mavi-kahverengi, mavi-siyah, beyaz-altın veya başka renklere bir geçiş olduğu bulunmuştur.

Sonuç: Elbisenin renk algısı ile lateralite arasında kısıtlı bilgi bulunduğu için bu çalışma gerçekleştirilmiş olup bu iki konu arasında anlamlı bir ilişki ilk kez bu çalışmada rapor edilmiştir.

Anahtar Kelimeler: Kol kavuşturma, el tercihi, lateralite, elbise, dil kıvirma

identical: each half of the brain has functional specializations (1). The asymmetries of two hemispheres were generally reported as the left hemisphere is analytical, logical and calculating 
whereas the right hemisphere is holistic, visual, spatial and emotional (2). Categorical perception of color is reported as another lateralized function of brain hemispheres (3). Additionally, a lateralized specialization of brain has been hypothesized by Brown et al. (4) for color perception (5).

In February 2015, a photograph of a dress started a debate about the colors of the dress: People are divided into two groups as blue-black or whitegold worldwide (6). The researchers started to investigate the answer of the question: "Why the different people see the colors of the dress differently without changing any condition of the picture?" (7). Picture of "the dress" is defined as an extreme example of categorical perception (8). The categorical perception of color is suggested to be lateralized to the left hemisphere in adults (3). It was reported other asymmetries: e.g. eyedness, footedness and earedness were also closely connected with the occurrence of asymmetrical handedness (9). There were studies about the relationship between left-right hemispheric specialization of brain and handedness (10) or color perception (4). Although there is a study about the dress color perception between right and left-handed participants in multiple sclerosis patients and general population (5), there is no study about the relationship between body lateralization and the color perception of the dress.

Lafer-Sousa et al. (11) suggest that differences in color perception of the dress might be due to aging, gender or spending more time on artificial light or daylight. Therefore, we chose a study population that consists of a young, healthy individual group which are at close ages and spent their time mostly at similar conditions.

The present study aims to investigate the relationship between the color perception of the dress and handedness, footedness, earedness, eyedness, hand clasping, hand clapping, arm folding, chewing side preference, leg crossing, tongue rolling, earlobe attachment and blood groups in young healthy individuals.

\section{Materials and Methods}

Participants: The Ethical approval was obtained prior to the study and performed in accordance with good clinical practice and the Declaration of Helsinki.

The present study is a prospective survey study conducted with 240 young individuals (male: 120 and female: 120, mean age: 20.62). All of them are students of Yuzuncu Yil University, Faculty of Medicine, Van, Turkey.

Study design: The subjects were asked to view the dress image on their personal electronic devices (e.g. smart phones, laptops) (7), three times: morning, noon and evening, on the first test day. In addition, the subjects were also viewed the image one more time on the third test day. The subjects were divided into five groups regarding as the color perception of the dress on the first and third test day: blue-black (BK), whitegold (WG), blue-brown (BB), something else (SE) and switchers $(\mathrm{SW})$.

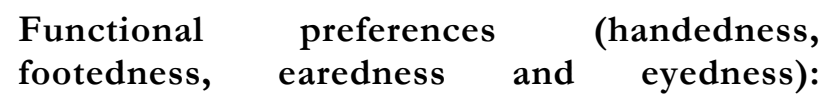
Handedness was evaluated with Edinburgh handedness inventory (12). The laterality degrees were also assessed by Geschwind scores $(13,14)$. In this study, handedness was classified as three categories: left handers (GS between -20 and 100), right handers (GS between 20 and 100) and mixed handers (GS between -15 and +15 ).

Four items which are kicking a ball, climbing up the first step of stairs (first foot forward), stepping off moving stairs (first foot off), and stepping on the pedal of a bin were considered to determine footedness (15).

Two items were used to determine earedness: listening a call (when two hands are free), listening a whispering person (15) who is standing in front of you.

Eyedness was assessed with two different tests: Rosenbach test (16) was applied as follows: subjects were asked to take aim at a distant target with their index fingers while their both eyes are open. Without moving arm and head, then they were asked to close one of their eyes by turn. The subject's finger and target were at the same alignment when dominant eye is open. Whereas, the index finger appears slid towards one side of the target when looking at the other eye (17). In the second method (paper tube), the subjects were asked to look through a paper tube and the preferred eye was noted (18).

Postural lateral preferences (Hand clasping, arm folding, hand clapping and leg crossing): The subjects were asked to perform hand clasping and arm folding. Lateral preferences were assessed as which thumb was on top for hand clasping and fingers of which hand were on top for arm folding. When fingers of left hand were on top, this was considered as right arm folding or vice versa (19). 
The hand clapping was defined as the hand in the upper position when two hands are first clapped (20). Leg crossing preference was determined by observing subjects cross their left leg over the right leg or right leg over the left one (21).

Chewing side preference: Chewing side preference was determined by asking the subjects whether their preferred chewing side was right, left or mixed (22).

The earlobe attachment and tongue rolling: The earlobe attachment was determined by physical observation (23). The tongue rolling was determined as follows: The subjects were asked to turn up the lateral edges of their tongues. They were classified into positive group in case ability to do (24).

Blood groups: Blood groups of the subjects were noted by asking to them or considering identity card.

Statistical Analysis: Descriptive statistics for the continuous variables (characteristics) were presented as mean, standard deviation, minimum and maximum values while count and percent for the categorical variables. Chi-Square test was calculated for determination relationships between the categorical variables. Statistical significance level was considered as $5 \%$ and SPSS (ver: 20 ) statistical program was used for all statistical computations.

\section{Results}

There was no statistically significant relationship between gender and color perception of the dress. $18.3 \%$ of participants described the dress as BK, $40.4 \%$ as $\mathrm{WG}, 5.4 \%$ as $\mathrm{BB}, 20.8 \%$ as $\mathrm{SW}$ and
$15.0 \%$ as SE. According to the gender, distributions were $58.0 \%$ male and $42.0 \%$ female in SW group, $50.0 \%$ male and $50.0 \%$ female in SE group, $30.8 \%$ male and $69.2 \%$ female in BB group, $40.9 \%$ male and $59.1 \%$ female in BK group, $52.6 \%$ male and $47.4 \%$ female in WG group (Table 1).

$20.8 \%$ of subjects were observed as switcher for the dress perception. From these subjects, 20\% of them switched from BK initially to WG, BB or SE while $28 \%$ from WG initially to $\mathrm{BK}, \mathrm{SE}$ and $\mathrm{BB}$; $18 \%$ from BB initially to WG, BK and SE; $34 \%$ from SE initially to $\mathrm{BB}, \mathrm{BK}, \mathrm{WG}$ and different color of SE (Table 2).

There was no significant relationship between a switch in the perceived color of the dress and handedness, gender, footedness, earedness, eyedness (paper tube), eyedness (Rosenbach test), hand clasping, hand clapping, arm folding, leg crossing, chewing side, earlobe attachment, tongue rolling as well as blood groups. $95.8 \%$ of SW is right handers, $2.1 \%$ is left handers and $2.1 \%$ is mixed handers. In SE group $97.1 \%$ are right handers, $2.9 \%$ is left handers and $0.0 \%$ is mixed handers. All subjects are right handers in $\mathrm{BB}$ group. $86.0 \%$ of BK is right handers, $9.3 \%$ is left handers and $4.7 \%$ is mixed handers. $89.9 \%$ of WG is right handers, $7.9 \%$ is left handers and 2.2 $\%$ is mixed handers (Table 1 ).

$42.3 \%$ of the subjects are right arm folder while $57.7 \%$ of left arm folder. We found a significant relationship between arm folding and groups $(\mathrm{p}<0.01)$ (Table 3). As shown in Figure 1, the rates of right arm folding were $52.0 \%$ in SW, $16.7 \%$ in $\mathrm{SE}, 30.8 \%$ in $\mathrm{BB}, 37.2 \%$ in $\mathrm{BK}$ and $50.5 \%$ in WG groups (Table 1). Similarly, there

Relationship between groups and arm folding

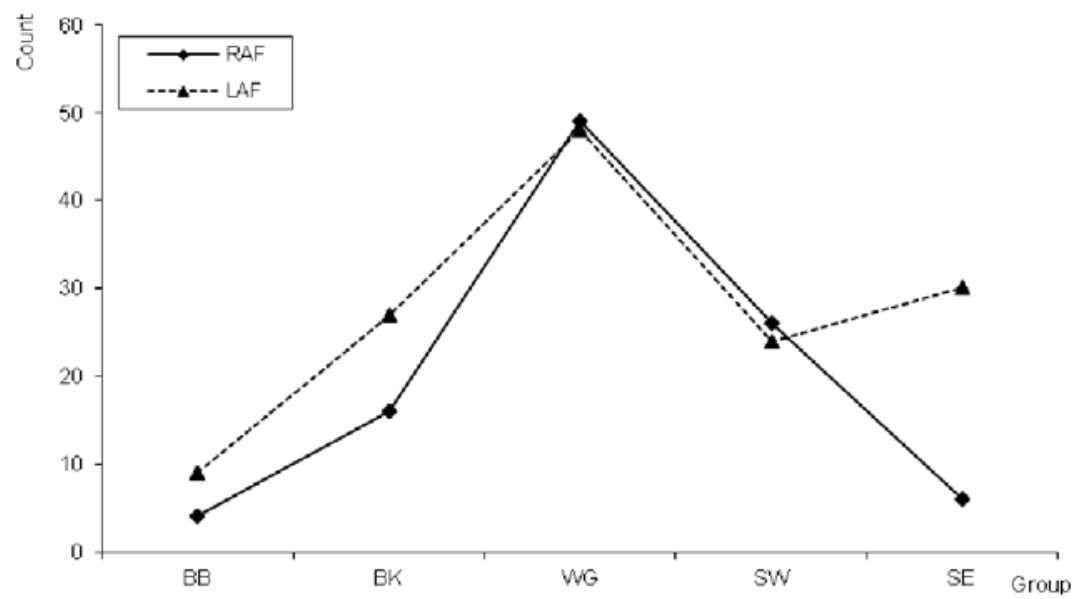

Fig. 1. The relationship between groups and arm folding. Values are expressed as mean. (RAF: Right arm folding, LAF: Left arm folding, BB: blue-brown, BK: blue-black, WG: white-gold, SW: switch, SE: something else).

Van Tip Derg Cilt:24, Sayı:4, Ekim/2017 
Erkeç et al. / The Dress and Lateral Preferences

Table 1. Descriptive statistics and results of the statistical significance tests for the relationships among the traits

\begin{tabular}{|c|c|c|c|c|c|c|c|c|c|c|c|c|c|}
\hline & & \multicolumn{2}{|c|}{ SW } & \multicolumn{2}{|c|}{$\mathrm{SE}$} & \multicolumn{2}{|c|}{$\mathrm{BB}$} & \multicolumn{2}{|c|}{$\mathrm{BK}$} & \multicolumn{2}{|c|}{ WG } & \multirow[b]{2}{*}{$\begin{array}{l}\text { Chi- } \\
\text { Square } \\
\left(\chi^{2}\right)\end{array}$} & \multirow[b]{2}{*}{ pValue } \\
\hline & & $\mathrm{n}=$ & $\%$ & $\mathrm{n}=$ & $\%$ & $\mathrm{n}=$ & $\%$ & $n=$ & $\%$ & $n=$ & $\%$ & & \\
\hline \multirow{3}{*}{$\begin{array}{l}\text { Color } \\
\text { perception } \\
\text { of the dress }\end{array}$} & Male & 29 & 58.0 & 18 & 50.0 & 4 & 30.8 & 18 & 40.9 & 51 & 52.6 & \multirow{3}{*}{4.915} & \multirow{3}{*}{0.296} \\
\hline & Female & 21 & 42.0 & 18 & 50.0 & 9 & 69.2 & 26 & 59.1 & 46 & 47.4 & & \\
\hline & Total & 50 & 20.8 & 36 & 15.0 & 13 & 5.4 & 44 & 18.3 & 97 & 40.4 & & \\
\hline \multirow{3}{*}{ Handedness } & Right & 46 & 95.8 & 33 & 97.1 & 13 & 100.0 & 37 & 86.0 & 80 & 89.9 & \multirow{3}{*}{6.668} & \multirow{3}{*}{0.573} \\
\hline & Left & 1 & 2.1 & 1 & 2.9 & 0 & 0.0 & 4 & 9.3 & 7 & 7.9 & & \\
\hline & Mixed & 1 & 2.1 & 0 & 0.0 & 0 & 0.0 & 2 & 4.7 & 2 & 2.2 & & \\
\hline \multirow{3}{*}{ Footedness } & Right & 39 & 78.0 & 29 & 80.6 & 11 & 84.6 & 34 & 77.3 & 75 & 77.3 & \multirow{3}{*}{6.227} & \multirow{3}{*}{0.622} \\
\hline & Left & 5 & 10.0 & 2 & 5.6 & 2 & 15.4 & 7 & 15.9 & 8 & 8.2 & & \\
\hline & Mixed & 6 & 12.0 & 5 & 13.9 & 0 & 0.0 & 3 & 6.8 & 14 & 14.4 & & \\
\hline \multirow{3}{*}{ Earedness } & Right & 35 & 70.0 & 20 & 55.6 & 8 & 61.5 & 29 & 65.9 & 58 & 59.8 & \multirow{3}{*}{3.262} & \multirow{3}{*}{0.917} \\
\hline & Left & 4 & 8.0 & 5 & 13.9 & 1 & 7.7 & 5 & 11.4 & 14 & 14.4 & & \\
\hline & Mixed & 11 & 22.0 & 11 & 30.6 & 4 & 30.8 & 10 & 22.7 & 25 & 25.8 & & \\
\hline \multirow{3}{*}{$\begin{array}{l}\text { Eyedness } \\
\text { (paper tube) }\end{array}$} & Right & 32 & 65.3 & 22 & 68.8 & 9 & 69.2 & 31 & 70.5 & 68 & 73.9 & & \\
\hline & Left & 16 & 32.7 & 10 & 31.2 & 4 & 30.8 & 11 & 25.0 & 22 & 23.9 & 3.699 & 0.883 \\
\hline & Mixed & 1 & 2.0 & 0 & 0.0 & 0 & 0.0 & 2 & 4.5 & 2 & 2.2 & & \\
\hline Eyedness & Right & 30 & 60.0 & 24 & 68.6 & 11 & 84.6 & 26 & 59.1 & 67 & 69.8 & & \\
\hline (Rosenbach & Left & 19 & 38.0 & 10 & 28.6 & 2 & 15.4 & 18 & 40.9 & 27 & 28.1 & 6.234 & 0.621 \\
\hline test) & Mixed & 1 & 2.0 & 1 & 2.9 & 0 & 0.0 & 0 & 0.0 & 2 & 2.1 & & \\
\hline & Right & 41 & 82.0 & 27 & 75.0 & 12 & 100.0 & 33 & 76.7 & 82 & 84.5 & & \\
\hline Hand & Left & 8 & 16.0 & 8 & 22.2 & 0 & 0.0 & 9 & 20.9 & 12 & 12.4 & 5.744 & 0.676 \\
\hline clapping & Mixed & 1 & 2.0 & 1 & 2.8 & 0 & 0.0 & 1 & 2.3 & 3 & 3.1 & & \\
\hline Hand & Right & 26 & 52.0 & 13 & 36.1 & 5 & 41.7 & 17 & 38.6 & 47 & 48.5 & & \\
\hline clasping & Left & 24 & 48.0 & 23 & 63.9 & 7 & 58.3 & 27 & 61.4 & 50 & 51.5 & 3.374 & 0.497 \\
\hline & Right & 38 & 76.0 & 23 & 63.9 & 8 & 61.5 & 30 & 68.2 & 73 & 75.3 & & \\
\hline Leg crossing & Left & 6 & 12.0 & 8 & 22.2 & 5 & 38.5 & 8 & 18.2 & 20 & 20.6 & 11.330 & 0.184 \\
\hline & Mixed & 6 & 12.0 & 5 & 13.9 & 0 & 0.0 & 6 & 13.6 & 4 & 4.1 & & \\
\hline & Right & 26 & 52.0 & 6 & 16.7 & 4 & 30.8 & 16 & 37.2 & 49 & 50.5 & & \\
\hline Arm folding & Left & 24 & 48.0 & 30 & 83.3 & 9 & 69.2 & 27 & 62.8 & 48 & 49.5 & 15.470 & $0.004 * *$ \\
\hline & Right & 28 & 57.1 & 21 & 58.3 & 4 & 30.8 & 26 & 61.9 & 60 & 62.5 & & \\
\hline Chewing side & Left & 10 & 20.4 & 10 & 27.8 & 5 & 38.5 & 8 & 19.0 & 16 & 16.7 & & \\
\hline & Mixed & 11 & 22.4 & 5 & 13.9 & 4 & 30.8 & 8 & 19.0 & 20 & 20.8 & 7.288 & 0.506 \\
\hline Ear lobe & Positive & 40 & 80.0 & 27 & 75.0 & 10 & 76.9 & 31 & 70.5 & 74 & 77.9 & 1383 & 0847 \\
\hline attachment & Negative & 10 & 20.0 & 9 & 25.0 & 3 & 23.1 & 13 & 29.5 & 21 & 22.1 & 1.383 & 0.847 \\
\hline Tongue & Positive & 19 & 38.0 & 12 & 33.3 & 10 & 76.9 & 15 & 34.1 & 34 & 35.1 & 9 350 & $0050 *$ \\
\hline rolling & Negative & 31 & 62.0 & 24 & 66.7 & 3 & 23.1 & 29 & 65.9 & 63 & 64.9 & Ү.ग59 & 0.050 \\
\hline & $\mathrm{A} \mathrm{Rh}^{+}$ & 13 & 31.0 & 13 & 31.0 & 4 & 30.8 & 17 & 40.5 & 33 & 38.8 & & \\
\hline & $\mathrm{A} \mathrm{rh}^{-}$ & 0 & 0.0 & 0 & 0.0 & 0 & 0.0 & 1 & 2.4 & 5 & 5.9 & & \\
\hline & $\mathrm{B} \mathrm{Rh}^{+}$ & 8 & 19.0 & 8 & 19.0 & 2 & 15.4 & 4 & 9.5 & 9 & 10.6 & & \\
\hline Blood & $\mathrm{B} \mathrm{rh}-$ & 1 & 2.4 & 1 & 2.4 & 0 & 0.0 & 1 & 2.4 & 3 & 3.5 & & \\
\hline groups & $\mathrm{AB} \mathrm{Rh}^{+}$ & 7 & 16.7 & 7 & 16.7 & 3 & 23.1 & 3 & 7.1 & 4 & 4.7 & 23.216 & 0.507 \\
\hline & $\mathrm{AB} \mathrm{rh}^{-}$ & 0 & 0.0 & 0 & 0.0 & 0 & 0.0 & 0 & 0.0 & 0 & 0.0 & & \\
\hline & $0 \mathrm{Rh}^{+}$ & 12 & 28.6 & 12 & 28.6 & 4 & 30.8 & 16 & 38.1 & 28 & 32.9 & & \\
\hline & $0 \mathrm{rh}^{-}$ & 1 & 2.4 & 1 & 2.4 & 0 & 0.0 & 0 & 0.0 & 3 & 3.5 & & \\
\hline
\end{tabular}

(SW: switch, SE: something else color, BB: blue-brown, BK: blue-black WG: white-gold, *: p<0.05 **: p<0.01).) 
Table 2. Switch group

\begin{tabular}{llllllll}
\hline $\begin{array}{l}\text { Initially } \\
\text { color }\end{array}$ & $\mathrm{n}=$ & $\%$ & \multicolumn{5}{c}{ Switch to } \\
\cline { 5 - 8 } $\begin{array}{l}\text { perception } \\
\text { of the dress }\end{array}$ & & & $\begin{array}{l}\mathrm{BK} \\
\%\end{array}$ & $\begin{array}{l}\mathrm{WG} \\
\%\end{array}$ & $\begin{array}{l}\mathrm{BB} \\
\%\end{array}$ & $\begin{array}{l}\mathrm{SE} \\
\%\end{array}$ \\
\hline BK & 10 & 20.00 & - & 60.00 & 10.00 & 30.00 \\
WG & 14 & 28.00 & 42.85 & - & 7.14 & 50.01 \\
BB & 9 & 18.00 & 33.33 & 33.33 & - & 33.33 \\
SE & 17 & 34.00 & 11.76 & 35.29 & 5.88 & 47.05 \\
\hline
\end{tabular}

(SW: switch, SE: something else color, BB: bluebrown, BK: blue-black WG: white-gold)

was also significant relationship between arm folding and eyedness (paper tube) $(\mathrm{p}<0.05)$ (Table
3). The rates of right arm folding $78.0 \%$ in right eyedness, $19.0 \%$ in left eyedness and $3.0 \%$ in no preferred eye side.

As shown in Figure 2, there was a significant relationship between tongue rolling ability and the groups $(p<0.05)$ (Table 3$)$. The rates of tongue rolling ability were $38.0 \%$ in SW, $33.3 \%$ in SE, $76.9 \%$ in $\mathrm{BB}, 34.1 \%$ in $\mathrm{BK}, 35.1 \%$ in $\mathrm{WG}$ groups (Table 1). There were no significant relationships between color perception of the dress and gender, handedness, footedness, earedness, eyedness (Rosenbach test), hand clapping, hand clasping, leg crossing, earlobe attachment, preferred chewing side as well as blood groups (Table 3).

Table 3. Chi-square values for the relationships among the traits

\begin{tabular}{|c|c|c|c|c|c|c|c|c|c|c|c|c|c|c|c|}
\hline & $\hat{\mathrm{U}}$ & $\begin{array}{c}\vec{D} \\
\vec{D} \\
0 \\
0\end{array}$ & 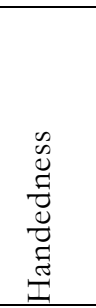 & $\begin{array}{l}0 \\
0 \\
0 \\
\tilde{E} \\
0 \\
\mathbb{D} \\
0 \\
0 \\
0\end{array}$ & 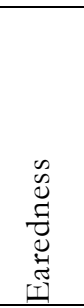 & 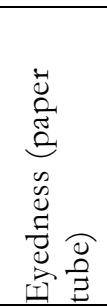 & 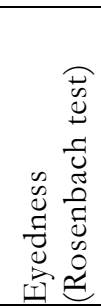 & 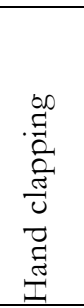 & 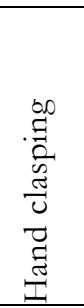 & 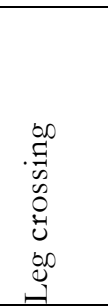 & 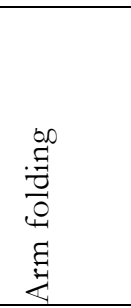 & 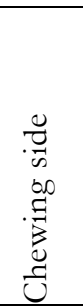 & 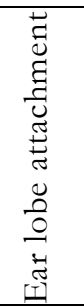 & 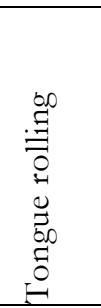 & $\begin{array}{l}0 \\
\overrightarrow{0} \\
0 \\
0 \\
0 \\
0 \\
0 \\
\frac{0}{9}\end{array}$ \\
\hline CPD & - & 4.92 & 6.67 & 6.23 & 3.26 & 3.70 & 6.23 & 5.74 & 3.37 & 11.33 & $15.47 * *$ & 7.29 & 1.38 & $9.36^{*}$ & 23.22 \\
\hline $\mathrm{AF}$ & $15.47 * *$ & 1.52 & 0.59 & 0.41 & 1.86 & $6.71 *$ & 0.77 & 1.23 & 2.54 & 0.01 & - & 3.05 & 0.65 & 0.84 & 5.37 \\
\hline TR & $9.36 *$ & 2.56 & 1.06 & 3.85 & 1.73 & 1.49 & 0.53 & 2.28 & 0.56 & 0.58 & 0.84 & 2.65 & 0.07 & - & 3.95 \\
\hline
\end{tabular}

(CPD: Color perception of the dress, AF: Arm-folding, TR: Tongue rolling ability. *: p<0.05 **: p<0.01).

\section{Relationship between groups and tongue rolling}

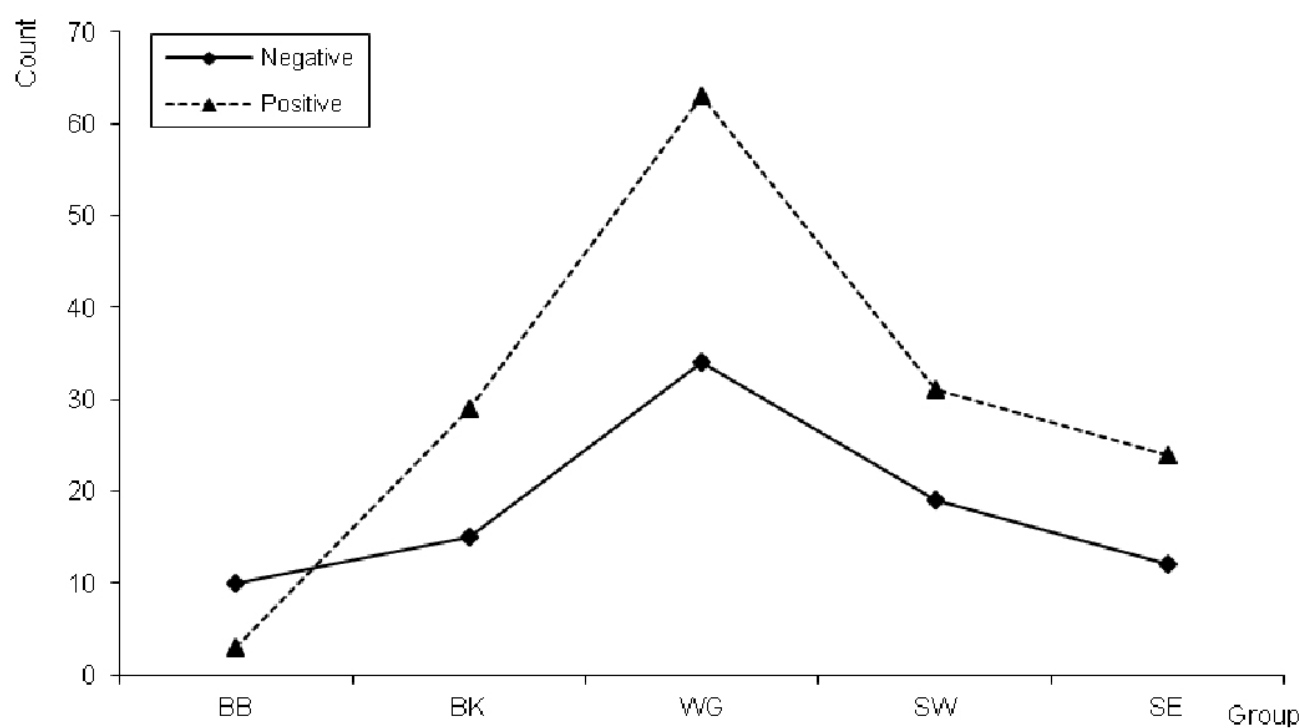

Fig. 2. The relationship between groups and tongue rolling ability. Values are expressed as mean. (Positive: Having tongue rolling ability, Negative: Do not have tongue rolling ability, BB: blue-brown, BK: blue-black, WG: white-gold, SW: switch, SE: something else). 


\section{Discussion}

We investigated the relationships between color perception of the dress and functional, postural lateral preferences, some morphogenetic traits and chewing side preference in 240 young individuals. There were no significant relationships between groups and gender, handedness, footedness, earedness, eyedness, hand clapping, hand clasping, leg crossing, earlobe attachment, blood groups and preferred chewing side (Table 1). Consistent with our results, no significant differences in hand dominance (5) and gender were found for the color vision of the dress $(5,7)$.

We found a significant relationship between arm folding and the color perception of the dress groups, while there was no significant relationship between handedness and groups (Table 1). Arm folding was also reported as bilateral limb postures that show signs of lateral preferences like handedness (19). According to our results, color perception of the dress is likely to be related with brain lateralization.

We found a significant relationship between tongue rolling ability and the color perception of the dress (Table 1). Sturtevant (24) suggested that tongue rolling ability was an inherited character. On the other hand, Martin (25) reported that there was no proof for a genetic base of tongue rolling. In a more recent study, it was emphasized that tongue rolling is likely to be product of autosomal genes (26).

Our result indicated that there was no significant relationship between tongue rolling ability and other investigated parameters (Table 3). Consistent with our results, in the study of Sturtevant (24), non-significant relationship was found between tongue rolling and gender. Nwaopara et al. (23), reported that a higher rate of the studied population have tongue rolling ability. Similarly, we also found that most of the study population has tongue rolling ability.

In this study some subjects reported a switch in perception (Table 2). Consistent with our findings previous studies reported a switch $(7,11)$. Furthermore, Vemuri et al. (7) reported the switch from white/gold-brown initially to blue/black.

In conclusion, there were significant relationships between color perception of the dress and arm folding as well as tongue rolling. Our results revealed that right arm folding and tongue rolling ability rates are higher in the WG group than the others. In our study, a switch in perception was found from blue-brown, blue-black, white-gold or something else colors initially to blue-brown, blueblack, white-gold or something else colors. Furthermore, more studies are required to determine whether larger study population or different test methods alters the relationship between color perception of the dress and lateralization traits.

Disclosure statement: No potential conflict of interest was reported by the authors.

\section{References}

1. Holder MK. What Does Handedness Have to Do with Brain Lateralization (and Who Cares?). http:/ / www.indiana.edu/ primate/brain.html (ET: 20.06.2016)

2. Bosman RA. Librarians and left-handedness: A speculative exploration. MS, University of North Carolina, Chapel Hill, North Carolina, 2004.

3. Franklin A, Drivonikou GV, Bevis L, Davies IR, Kay P, Regier T. Categorical perception of color is lateralized to the right hemisphere in infants, but to the left hemisphere in adults. Proc Natl Acad Sci U S A 2008; 105(9): 3221-3225.

4. Brown AM, Lindsey DT, Guckes KM. Color names, color categories, and color-cued visual search: Sometimes, color perception is not categorical. J Vis 2011; 11(12): 1-21.

5. Moccia M, Lavorgna L, Lanzillo R, Morra VB, Tedeschi G, Bonavita S. The Dress: Transforming a web viral event into a scientific survey. Mult Scler Relat Disord 2016; 7: 41-46.

6. Brainard DH, Hurlbert AC. Colour vision: understanding \#TheDress. Curr Biol 2015; 25(13): 551-554.

7. Vemuri K, Bisla K, Mulpuru S, Varadharajan S. Do normal pupil diameter differences in the population underlie the color selection of \# thedress? J Opt Soc Am A Opt Image Sci Vis 2016; 33(3): 137-142.

8. Netburn D. Science explains how time spent outdoors colors your view of \#thedress http://www.latimes.com/science/sciencenow/lasci-sn-scientific-papers-the-dress-20150513story.html (ET: 20.06.2016)

9. Singh, B. Handedness, footedness and familial sinistrality among normal individuals. JCPR 2015; 2: 32-39.

10. Annett M. Hand preference and the laterality of cerebral speech. Cortex 1975; 11(4): 305-328.

11. Lafer-Sousa R, Hermann KL, Conway BR. Striking individual differences in color perception uncovered by 'the dress' photograph. Curr Biol 2015; 25(13): 545-546.

12. Oldfield RC. The assessment and analysis of handedness: the Edinburgh inventory. Neuropsychologia 1971; 9(1): 97-113. 
13. Geschwind N, Behan P. Left-handedness: Association with immune disease, migraine, and developmental learning disorder. Proc Natl Acad Sci U S A 1982; 79(16): 5097-5100.

14. Tan Ü. The distribution of the Geschwind scores to familial left-handedness. Int J Neurosci 1988; 42(12): 85-105.

15. Lawton CA, Czarnolewski MY, Eliot J. Laterality, sex, and everyday spatial behaviours: an exploratory analysis. Laterality 2016; 21(4-6): 745-766.

16. Rosenbach O. Ueber monokulare Vorherrschaft beim binikularen Sehen. Munch Med Wochenschr 1903; 30: 1290-1292.

17. Aliosmanoğlu B, Köçkar Ç. Üniversite öğrencilerinde el tercihinin ve dominant gözün bazı hastalıklar ile ilişkisi. Eur J Basic Med Sci 2014; 4(3): 53-57.

18. Haryck C, Goldman R, Petrinovich L. Handedness and sex, race, and age. Hum Biol 1975; 47(3): 369375.

19. Tran US, Koller I, Nader IW, Pietschnig J, Schild $\mathrm{AH}$, Stieger S, et al. Lateral preferences for hand clasping and arm folding are associated with handedness in two large-sample latent variable analyses. Laterality 2014; 19(5): 602-614.
20. Combs AL. Patterns of lateral preference: Hand, eye, thumb and clapping. Percept Mot Skills 1983; 57(3): 847-850.

21. Park Y, Bae Y. Comparison of postures according to sitting time with the leg crossed. J Phys Ther Sci 2014; 26(11): 1749-1752.

22. Bicaj T, Pustina T, Ahmedi E, Dula L, Lila Z, Tmava-Dragusha A, et al. The Relation between the Preferred Chewing Side and Occlusal Force Measured by T-Scan III System. OJST 2015; 5: $95-$ 101.

23. Nwaopara AO, Anibeze CIP, Apkuaka FC, Agbontaen OF. Morphogenetic traits combination pattern amongst the population of Ekpoma, Nigeria: Focus on tongue rolling, ear lobe attachment, blood groups and genotypes. Afr J Biotechnol 2008; 7(20): 3593-3598.

24. Sturtevant AH. A new inherited character in man. Proc Natl Acad Sci U S A 1940; 26(2): 100102.

25. Martin NG. No evidence for a genetic basis of tongue rolling or hand clasping. J Hered 1975; 66(3): 179-180.

26. Odokuma EI, Eghworo O, Avwioro G, Agbedia U. Tongue rolling and tongue folding traits in an African population. Int J Morphol 2008; 26(3): 533535. 